\title{
Platinum(II) Compounds of Tetracyclines as Potential Anticancer Agents: Cytotoxicity, Uptake and Interactions with DNA
}

\author{
Priscila P. Silva, ${ }^{a}$ Flávia C. S. de Paula, ${ }^{a}$ Wendell Guerra, ${ }^{a, \#}$ Josianne N. Silveira, ${ }^{b}$ \\ Françoise V. Botelho, ${ }^{c}$ Leda Q. Vieira, ${ }^{c}$ Tiago Bortolotto, ${ }^{d}$ Franciele L. Fischer, ${ }^{d}$ \\ Giselle Bussi, ${ }^{d}$ Hernán Terenzi ${ }^{d}$ and Elene C. Pereira-Maia ${ }^{* a}$
}

\author{
${ }^{a}$ Departamento de Química, ${ }^{b}$ Departamento de Análises Clínicas e Toxicológicas and \\ 'Departamento de Bioquímica e Imunologia, Universidade Federal de Minas Gerais, \\ Av. Antônio Carlos, 6627 - Pampulha, 31270-901 Belo Horizonte-MG, Brazil \\ ${ }^{d}$ Centro de Biologia Molecular Estrutural, Departamento de Bioquímica, \\ Universidade Federal de Santa Catarina, Campus Reitor João David Ferreira Lima, \\ Bairro Trindade, 88040-970 Florianópolis-SC, Brazil
}

\begin{abstract}
As propriedades antitumorais de complexos de $\mathrm{Pt}^{\mathrm{II}} \mathrm{e}$ as características favoráveis das tetraciclinas levaram-nos a estudar compostos de $\mathrm{Pt}^{\mathrm{II}}$ da tetraciclina (tc) e doxiciclina (dox) como candidatos a agentes antitumorais. $\left[\mathrm{PtCl}_{2}(\mathrm{dox})\right], \mathbf{1}$, é mais potente que $\left[\mathrm{PtCl}_{2}(\mathrm{tc})\right], \mathbf{2}$, em inibir o crescimento de células de leucemia mielóide crônica. Os compostos $\mathbf{1}$ e $\mathbf{2}$ formam um complexo

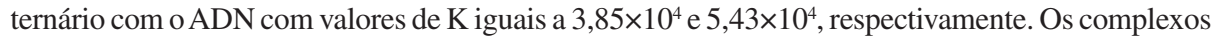
deslocam o brometo de etídeo dos sítios no ADN, o que indica um mecanismo intercalativo. Ambos os complexos diminuem a mobilidade eletroforética e a temperatura de fusão do ADN. Após a incubação das células com $\mathbf{1}$ e 2, o ADN foi extraído e os adutos formados foram quantificados. Na concentração em que os compostos são citotóxicos contra células cancerosas, eles não afetam a viabilidade de macrófagos. A velocidade de entrada do complexo da doxiciclina nas células é três vezes maior do que a do complexo da tetraciclina e isto parece ser determinante para a sua maior atividade.
\end{abstract}

The antitumoral properties of $\mathrm{Pt}^{\mathrm{II}}$ compounds and the favorable characteristics of tetracyclines led us to study $\mathrm{P}^{\mathrm{II}}$ compounds of tetracycline (tc) and doxycycline (dox) as candidates for anticancer agents. $\left[\mathrm{PtCl}_{2}(\mathrm{dox})\right], \mathbf{1}$, is more potent than $\left[\mathrm{PtCl}_{2}(\mathrm{tc})\right], \mathbf{2}$, in inhibiting the growth of chronic myelogenous leukemia cells. Compounds $\mathbf{1}$ and $\mathbf{2}$ form a ternary complex with DNA with $\mathrm{K}$ values of $3.85 \times 10^{4}$ and $5.43 \times 10^{4}$, respectively. The compounds displace ethidium bromide from DNA sites, which points to an intercalative mechanism. Both complexes decrease DNA eletrophoretic mobility and melting temperature. After incubation of cells with $\mathbf{1}$ and $\mathbf{2}$, the DNA was extracted and the adducts formed were quantified. At the concentration that the compounds are cytotoxic to cancer cells, they do not affect macrophages viability. The rate of uptake of the doxycycline complex in cells is three times higher than that of the tetracycline complex and this seems to be determinant for its higher activity.

Keywords: platinum(II) compounds, cytotoxicity, cellular uptake, DNA binding

\section{Introduction}

cis-Diamminedichloroplatinum(II) (cisplatin) is one of the most important chemotherapeutic agents used in the treatment of a wide variety of solid tumors, ${ }^{1-4}$ and its

\footnotetext{
*e-mail: elene@qui.ufmg.br

" Present Address: Instituto de Química, Universidade Federal de Uberlândia-MG, Brasil
}

interaction with DNA is pointed out as the main mechanism of cytotoxic action. ${ }^{5,6}$ Despite the important contribution of cisplatin in cancer therapy, its use presents limitations such as development of resistance and side effects, which has stimulated the design of novel compounds..$^{7-13}$

The use of antibiotics that interact with DNA represents an interesting strategy. The antibiotics of the tetracycline family have several advantages over the currently known agents, such as broad spectrum of action, low toxicity, 
oral administration and low cost. The main mechanism of tetracycline antimicrobial action is the inhibition of protein synthesis.

Tetracyclines are good proligands for different metal ions because they possess diverse potential metal binding sites: oxygens at the $\mathrm{C} 1-\mathrm{C} 3$ tricarbonyl system or $\mathrm{O} 1$ and the amide oxygen in ring A, oxygens at the C10-C12 system, and the nitrogen of the dimethylammonium group at N4. ${ }^{14}$ As a consequence, their pharmacological activities, pharmacokinetics and bioavailability are dictated by metal coordination. In blood plasma, the drug is transported as calcium complexes ${ }^{15}$ and, once inside bacterium cells, magnesium complexes are responsible for binding to ribosomes. ${ }^{16}$

Because of the favorable characteristics of tetracyclines, they were indiscriminately used, which led to the appearance of bacterial resistance to this family of drugs. ${ }^{17-21}$ Many efforts have been made to control the propagation of multidrug resistant strains worldwide. We synthesized platinum(II) and palladium(II) complexes with tetracycline and doxycycline, which are active against $E$. coli sensitive and resistant strains. ${ }^{22-24}$ Doxycycline has the same minimal formula as that of tetracycline: the difference between them lies in the presence of an $\mathrm{OH}$ group at $\mathrm{C} 5$ in doxycycline instead of C6 in tetracycline. In both cases, they form 1:1 complexes with platinum(II) via the oxygen atoms of the hydroxyl and the amide group in ring $\mathrm{A}$, and two chloride ions complete the coordination sphere in a square planar geometry around the metal ion. The proposed structures of the $\mathrm{Pt}^{\mathrm{II}}$ complexes of tetracycline and doxycycline are represented in Figure 1. The synthesis, characterization, and antibacterial effect of these compounds were described elsewhere. ${ }^{22,24}$ Dos Santos et al. ${ }^{25}$ carried out a theoretical study of $\mathrm{Pt}^{\mathrm{II}}$ coordination to anhydrotetracycline, in which they calculated the ${ }^{1} \mathrm{H}$ NMR spectra for different possible structures, compared them to our previous experimental results for the $\mathrm{Pt}^{\mathrm{II}}$ complex of tetracycline, and concluded that, in aqueous solution, the $\mathrm{Pt}^{\mathrm{II}}$ ion should be bound to $\mathrm{O} 3$ and the amide oxygen, according to our proposal. The same authors have shown that the reactivity of the $\mathrm{Pt}^{\mathrm{II}}$ compound of anhydrotetracycline towards several nucleophiles is similar to that of cisplatin. ${ }^{26}$

Tetracyclines also exhibit pharmacological properties other than antimicrobial activity. An example of interest in cancer therapy is the inhibition by doxycycline and other chemically modified tetracyclines of matrix metalloproteinases, which are members of the zincdependent metallopeptidases and implicated in major stages of cancer progression. As a consequence, matrix metalloproteinases became a new target for the treatment of cancer. ${ }^{27,}{ }^{28}$ Garcia et $a l .^{29}$ suggested that doxycycline
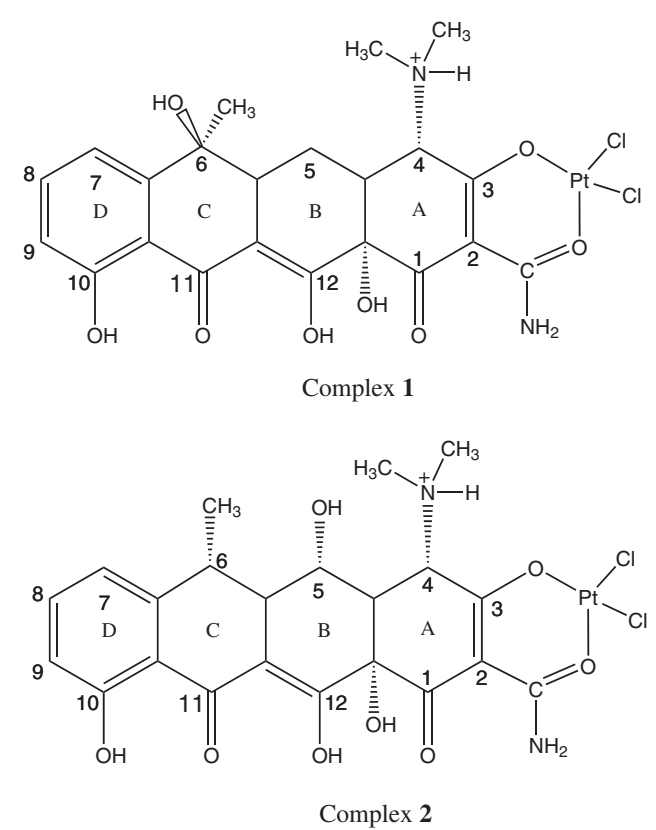

Figure 1. Proposed structures for compounds 1, $\left[\mathrm{PtCl}_{2}(\mathrm{dox})\right]$, and 2, $\left[\mathrm{PtCl}_{2}(\mathrm{tc})\right]$.

inhibition of metalloproteinase activity occurs through interactions with the structural zinc and/or calcium atoms of the protein.

Khan et al ${ }^{30,31}$ reported that, in the presence of copper(II) ions, tetracycline binds to DNA and breaks its strand probably with the involvement of reactive oxygen species.

In this study, we investigated the cytotoxicity, uptake and interactions of platinum(II) complexes of tetracycline (tc) and doxycycline (dox) with DNA. Our strategy was to ally the antitumoral properties of platinum compounds to the favorable properties of tetracyclines, such as low toxicity and broad spectrum of action.

\section{Experimental}

\section{Reagents, materials and methods}

All chemicals were reagent grade and were used without further purification. Doxycycline hydrochloride $(\mathrm{dox} \cdot \mathrm{HCl})$, tetracycline hydrochloride $(\mathrm{tc} \cdot \mathrm{HCl})$ and potassium tetrachloroplatinate were purchased from Sigma Chemical Company. Stock solutions were prepared just before use to avoid ligand degradation caused by oxygen and light. Platinum(II) complexes of tetracycline and doxycycline were synthesized as previously described. ${ }^{22,24}$ The complexes can be represented as $\left[\mathrm{PtCl}_{2}(\mathrm{dox})\right]$, complex $\mathbf{1}$, and $\left[\mathrm{PtCl}_{2}(\mathrm{tc})\right]$, complex 2 , in which tc and dox correspond to the same minimal formula, $\mathrm{C}_{22} \mathrm{H}_{24} \mathrm{O}_{8} \mathrm{~N}_{2}$. Calf thymus DNA sodium salt (CT DNA), 3-(4,5-dimethylthiazol2yl)-2,5-diphenyltetrazolium bromide (MTT) and 
sodium dodecyl sulfate (SDS) were used as obtained from Sigma. Ethidium bromide, 2,7- diamino-10-ethyl-6phenylphenanthridinium bromide (Eb), was bought from Gibco BRL. The plasmid pBSK-II (2961 bp), used for the DNA cleavage assays, was purchased from Stratagene, transformed into DH5 $\alpha$ Escherichia coli competent cells and amplified as previously described. ${ }^{32}$ The plasmid DNA was extracted from E. coli and purified using Qiagen Plasmid Maxi Kit protocol. ${ }^{33}$

${ }^{195} \mathrm{Pt}$ NMR (86 MHz) spectra were obtained using a Bruker Avance DRX 400 spectrometer in dmf- $d_{7}$. Electrospray ionisation-mass spectrometry (ESI-MS) studies, in positive ion mode, were carried out on a Bruker Daltonics Squire 3000 Plus equipment at the Central Analítica of Universidade de São Paulo. The complexes were dissolved in a few drops of dimethylformamide (dmf) and then diluted with a 1:1 $\mathrm{MeOH}: \mathrm{H}_{2} \mathrm{O}$ solution.

\section{Partition coefficient}

Partition coefficients of the complexes were determined in duplicate in an $n$-octanol/water system. Each complex was dissolved in $50 \mathrm{~mL}$ of water at $4 \times 10^{-5} \mathrm{~mol} \mathrm{~L}^{-1}$ and subsequently an equal volume of $n$-octanol was added. The mixtures were shaken mechanically for $24 \mathrm{~h}$ to insure the distribution between the two solvent phases. The samples were centrifuged (13,000 rpm for $5 \mathrm{~min})$. Afterwards, they were diluted 5-fold and the platinum concentration was determined in both phases by graphite furnace atomic absorption spectrometry (GFAAS) in a Varian model Zeeman 220 spectrophotometer equipped with a graphite tube atomizer and an autosampler. Results are expressed as apparent partition coefficients $(P)$, which were determined from the total metal concentration in $n$-octanol divided by the total metal concentration in the aqueous layer.

\section{Cell line and culture}

The K562 cell line was purchased from the Rio de Janeiro Cell Bank (number CR083 of the RJCB collection). K562 cell line was established from pleural effusion of a 53 year-old female with chronic myelogenous leukemia in terminal blast crisis. Cells were cultured in RPMI 1640 (Roswell Memorial Park Institute medium, Sigma Co.) supplemented with $10 \%$ of fetal calf serum (CulLab, São Paulo, Brazil) at $37^{\circ} \mathrm{C}$ in humidified $5 \% \mathrm{CO}_{2}$ atmosphere. Cultures initiated at $10^{5}$ cells mL $\mathrm{mL}^{-1}$ and grew exponentially to about $8 \times 10^{5}$ cells $\mathrm{mL}^{-1}$ in three days. Cell viability was checked by Trypan Blue exclusion with an optical microscope. Cell number was determined by Coulter counter analysis.
Drug sensitivity assay and determination of platinum cellular concentrations

Dose-response curves were obtained by incubating $1 \times 10^{5}$ cells $\mathrm{mL}^{-1}$ for $72 \mathrm{~h}$ in the absence and presence of various concentrations of tested compounds. The sensitivity to the drug was evaluated from the drug concentration needed to inhibit cell growth by 50\%, the $\mathrm{IC}_{50}$. Long-term measurements of platinum accumulation were made by incubating cells in the culture medium with various equitoxic drug concentrations for $72 \mathrm{~h}$. After incubation, an aliquot was taken, washed twice with icecold isotonic buffer and the pellet was resuspended in 33\% $\mathrm{HNO}_{3}$. Platinum concentration was determined by atomic absorption spectroscopy in a Varian model Zeeman 220 spectrophotometer equipped with a graphite tube atomizer and an autosampler.

Short-term measurements were performed by following the uptake of the platinum(II) compounds by K562 cells as a function of the incubation time up to $4 \mathrm{~h} .1 \times 10^{6}$ cells $\mathrm{mL}^{-1}$ were incubated with $1 \times 10^{-5} \mathrm{~mol} \mathrm{~L}^{-1}$ of compounds in an isotonic buffer $\left(132 \mathrm{mmol} \mathrm{L}^{-1} \mathrm{NaCl}, 3.5 \mathrm{mmol} \mathrm{L}^{-1} \mathrm{KCl}\right.$, $1 \mathrm{mmol} \mathrm{L}^{-1} \mathrm{CaCl}_{2}, 0.5 \mathrm{mmol} \mathrm{L} \mathrm{MgCl}_{2}, 20 \mathrm{mmol} \mathrm{L}^{-1}$ HEPES (4-(2-hydroxyethyl)-1-piperazineethanesulfonic acid), 5 mmol L-1 glucose) at $\mathrm{pH} 7.20$ and $37{ }^{\circ} \mathrm{C}$, under continuous stirring. At fixed time intervals, an aliquot was taken, washed twice with ice-cold isotonic buffer without glucose and the pellet was resuspended in $33 \% \mathrm{HNO}_{3}$. Platinum concentration was determined as described above.

\section{DNA binding}

K562 cells $\left(5 \times 10^{6}\right)$ were incubated with different concentrations of complexes $\mathbf{1}$ and $\mathbf{2}$ ranging from 10 to $300 \mu \mathrm{mol} \mathrm{L} \mathrm{L}^{-1}$ for $2 \mathrm{~h}$. Afterwards, DNA was extracted from cells, by using a kit from Sigma (Sigma's GenElute Mammalian Genomic DNA Miniprep Kit). ${ }^{33}$ DNA concentration per nucleotide was determined by spectrophotometric analysis $\left(\varepsilon=6600 \mathrm{~mol} \mathrm{~L}^{-1} \mathrm{~cm}^{-1}\right.$ at $260 \mathrm{~nm}$ ). The ratio of absorbance at $260 \mathrm{~nm}$ to $280 \mathrm{~nm}$ was between 1.6-1.9. Platinum concentration was determined by GFAAS.

\section{$U V$ and visible absorption measurements}

A Cary 100 spectrophotometer was used for UV and visible absorption measurements. For the interactions with CT DNA, the complex concentration used was $1.0 \times 10^{-4} \mathrm{~mol} \mathrm{~L}^{-1}$ and the DNA-to-complex molar ratios ranged from 0 to 4.5 . The DNA concentration per nucleotide was determined from $\varepsilon=6600 \mathrm{~mol} \mathrm{~L}^{-1} \mathrm{~cm}^{-1}$ 
at $260 \mathrm{~nm}$. The ionic strength was maintained constant with $1 \times 10^{-3} \mathrm{~mol} \mathrm{~L}^{-1} \mathrm{NaCl}$ and the $\mathrm{pH}$ was fixed at 7.3 with $20 \mathrm{mmol} \mathrm{L}^{-1}$ TRIS-HCl buffer. The absorbance of DNA itself was subtracted by adding equal quantity of DNA to both the complex and the reference solutions.

\section{Circular dichroism (CD)}

CD spectra of CT DNA modified by $\mathbf{1}$ and $\mathbf{2}$ were recorded at $25^{\circ} \mathrm{C}$ in $25 \mathrm{mmol} \mathrm{L}^{-1}$ TRIS buffer $\mathrm{pH} 7.0$ by using a Jasco J-815 spectropolarimeter equipped with a thermoelectrically controlled cell holder with a cell pathlength of $1 \mathrm{~cm}$. The spectrum was recorded in the range of 200-350 $\mathrm{nm}$ with an averaging time of $4 \mathrm{~s}$, speed $100 \mathrm{~nm} \mathrm{~min}{ }^{-1}$ and three accumulations. The spectrum of the corresponding buffer and of the complexes alone were collected and subtracted from that of the reaction mixture.

\section{Fluorescence measurements}

Fluorescence measurements were carried out on a Varian Cary Eclipse fluorescence spectrophotometer setting the excitation and emission slits at $5 \mathrm{~nm}$. Ethidium bromide was dissolved in $20 \mathrm{mmol} \mathrm{L}^{-1}$ TRIS-HCl buffer at $\mathrm{pH}$ 7.3. The DNA solution was prepared as described above. To a solution containing $10 \mu \mathrm{mol} \mathrm{L}^{-1}$ DNA and $8 \mu \mathrm{mol} \mathrm{L}^{-1} \mathrm{~Eb}$, increasing concentrations of the tested compounds were added and the emission spectra registered after excitation at $546 \mathrm{~nm}$. Tetracycline concentrations ranged from 0 to $1.49 \times 10^{-3} \mathrm{~mol} \mathrm{~L}^{-1}$; doxycycline concentrations from 0 to $2.91 \times 10^{-3} \mathrm{~mol} \mathrm{~L}^{-1}$; complex 1 concentrations ranged from 0 to $8.78 \times 10^{-5} \mathrm{~mol} \mathrm{~L}^{-1}$; and complex 2 from 0 to $1.43 \times 10^{-4} \mathrm{~mol} \mathrm{~L}^{-1}$.

\section{DNA thermal denaturation}

Thermal-denaturation experiments were carried out on an Ultrospec $2100 \mathrm{UV} / \mathrm{Vis}$ spectrophotometer (Amersham Bioscences, USA) equipped with a peltier temperature controller. UV absorbance of CT-DNA $\left(100 \mu \mathrm{mol} \mathrm{L}^{-1}\right)$ was recorded in melting buffer $\left(1 \mathrm{mmol} \mathrm{L}-1 \mathrm{NaH}_{2} \mathrm{PO}_{4} / \mathrm{Na}_{2} \mathrm{HPO}_{4}\right.$ $\left.\mathrm{pH} 7.2,2 \mathrm{mmol} \mathrm{L}^{-1} \mathrm{NaCl}\right)$. The melting curves were recorded at different concentration ratios of complexes to DNA $(r=0$ and $0.25, \mathrm{r}=$ [complex] / [DNA]) by plotting the absorption at $260 \mathrm{~nm}$ as function of temperature in the range of $25-75^{\circ} \mathrm{C}$ with a ramp rate of $1{ }^{\circ} \mathrm{C} \mathrm{min}^{-1}$. Before the start of ramping, the samples were equilibrated for $5 \mathrm{~min}$ at $25^{\circ} \mathrm{C}$. The melting temperature $\left(\mathrm{T}_{\mathrm{m}}\right)$ was determined from the midpoint of the transition curves fitted by sigmoidal non-linear regression. $\Delta \mathrm{T}_{\mathrm{m}}$ was defined as the difference between the $\mathrm{T}_{\mathrm{m}}$ of free DNA and the $\mathrm{T}_{\mathrm{m}}$ of DNA in the presence of $\mathbf{1}$ and $\mathbf{2}$.

\section{Plasmid DNA cleavage}

The ability of $\mathbf{1}$ and $\mathbf{2}$ to cleave DNA was examined by following the conversion of the supercoiled plasmid form (F I) to the open circular (F II) and/or linear forms (F III) using agarose gel electrophoresis to separate the cleavage products. In general, $330 \mathrm{ng}$ of pBSK-II $\left(25 \mu \mathrm{mol} \mathrm{L}^{-1}\right.$ in $\mathrm{pb})$ in PIPES buffer ( $\mathrm{pH}$ 7.0) were treated with different concentrations of $\mathbf{1}$ and $\mathbf{2}$ in $\mathrm{CH}_{3} \mathrm{CN}(25 \% \mathrm{v} / \mathrm{v})$ for $20 \mathrm{~h}$ at $50{ }^{\circ} \mathrm{C}$. Thereafter, each reaction was quenched by adding $5 \mu \mathrm{L}$ of a loading buffer solution (50 $\mathrm{mmol} \mathrm{L}^{-1}$ TRIS $\mathrm{pH} 7.5$, $0.01 \%$ bromophenol blue, $50 \%$ glycerol and $250 \mathrm{mmol} \mathrm{L}^{-1}$ EDTA) and then subjected to electrophoresis on a $0.8 \%$ agarose gel containing $0.3 \mu \mathrm{g} \mathrm{mL}^{-1}$ of ethidium bromide in $0.5 \times \mathrm{TBE}$ buffer ( $44.5 \mathrm{mmol} \mathrm{L}^{-1}$ TRIS, $44.5 \mathrm{mmol} \mathrm{L}^{-1}$ boric acid, and $1 \mathrm{mmol} \mathrm{L}^{-1}$ EDTA) at $90 \mathrm{~V}$ for about $1.5 \mathrm{~h}$. The resulting gels were visualized and digitized with a DigiDoc-It gel documentation system (UVP, USA).

\section{Plasmid DNA interaction by agarose gel mobility shift assay}

The ability of $\mathbf{1}$ and $\mathbf{2}$ to bind the plasmid DNA was evaluated by agarose gel eletrophoresis to detect changes in eletrophoretic mobility of pBSK-II treated with $\mathbf{1}$ and 2. Thus, $330 \mathrm{ng}$ of pBSK-II $\left(25 \mu \mathrm{mol} \mathrm{L}^{-1}\right.$ in $\left.\mathrm{pb}\right)$ in PIPES (pH 7.0) buffer were treated with different concentrations of 1 and 2 in $\mathrm{CH}_{3} \mathrm{CN}(25 \% \mathrm{v} / \mathrm{v})$ for $16 \mathrm{~h}$ at $50{ }^{\circ} \mathrm{C}$. Thereafter, the reactions were quenched by adding $5 \mu \mathrm{L}$ of a loading buffer solution $\left(50 \mathrm{mmol} \mathrm{L}^{-1}\right.$ TRIS $\mathrm{pH} 7.5$, $0.01 \%$ bromophenol blue, $50 \%$ glycerol and $250 \mathrm{mmol} \mathrm{L}^{-1}$ EDTA) and the mixture was subjected to electrophoresis on a $1.0 \%$ agarose gel in $0.5 \times \mathrm{TBE}$ buffer $\left(44.5 \mathrm{mmol} \mathrm{L}^{-1} \mathrm{TRIS}\right.$, $44.5 \mathrm{mmol} \mathrm{L}^{-1}$ boric acid, and $1 \mathrm{mmol} \mathrm{L}^{-1}$ EDTA) at $90 \mathrm{~V}$ for about $1.5 \mathrm{~h}$. The gels were stained after electrophoresis in $0.5 \times \mathrm{TBE}$ buffer with $2.5 \mu \mathrm{g} \mathrm{mL} \mathrm{m}^{-1}$ ethidium bromide for $15 \mathrm{~min}$.

\section{Mice}

Males and females of 4-8 weeks of the mouse strain C57BL/6 (CEBIO-UFMG, Belo Horizonte, Brazil) were used. Experimental animals were kept in a conventional animal house with barriers, temperature and light control. Food and water were offered ad libitum.

\section{Macrophages}

Inflammatory macrophages were obtained from the peritoneal cavity, 3 days after injection of $2 \mathrm{~mL}$ of $3 \%$ thioglicolate medium, containing $1 \%$ sterile agar (Biobrás S.A., Montes Claros, MG, Brazil). The animals were then 
sacrificed and $10 \mathrm{~mL}$ of sterile RPMI 1640 medium, without phenol red (Sigma Chemical Co., St Louis, MO, USA), were injected into the peritoneal cavity. The largest possible content was aspirated, and the cells were centrifuged at $4{ }^{\circ} \mathrm{C}$. The supernatant medium was discarded and cells were resuspended in RPMI 1640 medium without phenol red, supplemented with $10 \%$ fetal bovine serum (CultLab São Paulo, Brazil), $0.05 \mathrm{mmol} \mathrm{L}^{-1} \beta$-mercaptoethanol (Sigma Chemical Co.), $0.2 \%$ gentamicin and $200 \mathrm{mmol} \mathrm{L}^{-1}$ L-glutamine. The cells were counted in a Newbauer chamber, and the final concentration was adjusted for each experiment.

\section{Macrophages viability}

To evaluate the cellular viability, $2 \times 10^{5}$ cells $\mathrm{mL}^{-1}$ were incubated in the absence and presence of different concentrations of the studied compounds for 24,48 or $72 \mathrm{~h}$.

Cell viability was assessed using the MTT tetrazolium dye reduction assay. $100 \mu \mathrm{L}$ of $5 \mathrm{mg} \mathrm{mL}^{-1}$ MTT were added to $2 \times 10^{5}$ cells in duplicate wells of a 96 -well flat-bottom tissue culture plate and cells were incubated for $4 \mathrm{~h}$ at $37^{\circ} \mathrm{C}$. After $4 \mathrm{~h}, 100 \mu \mathrm{L}$ of SDS detergent were added to each well. The absorbance at $550 \mathrm{~nm}$ of each sample well was measured using an automated plate reader. The experiment was repeated at least twice.

\section{Results and Discussion}

As already mentioned, we investigated the cytotoxic activity and the interactions of $\mathrm{Pt}^{\mathrm{II}}$ complexes of tc and dox with DNA in order to evaluate their antitumoral potential. Although we were unable to grown crystals of $\mathbf{1}$ and $\mathbf{2}$ suitable to determine their structures by X-ray diffraction analysis, spectroscopic studies, including FTIR and ${ }^{1} \mathrm{H}$ NMR, led us to propose the structures represented in Figure 1. The ${ }^{195} \mathrm{Pt}$ NMR spectra of complex 2 (Supplementary Information, SI, Figure S1) and $\mathbf{1}$ (reported in a previous work) ${ }^{24}$ showed the presence of only one species. The ESI-MS studies confirmed the presence of the complexes in solution. For both complexes a peak at $m / z 728$ corresponds to the proposed formula plus a water molecule (SI, Figure S2).

\section{Drug sensitivity assay in K562 cells}

The concentration of compounds necessary to inhibit $50 \%$ of cell growth, $\mathrm{IC}_{50}$, and the octanol/water partition coefficient, $P$, are shown in Table 1.

Comparing the activity of the complexes to those of the proligands, one observes that complex $\mathbf{1}$ is $c a$. 3 times
Table 1. $\mathrm{IC}_{50}$, $\left[\mathrm{Pt}_{\mathrm{i}}\right]$ and $P$ values for the compounds $\left[\mathrm{PtCl}_{2}(\mathrm{dox})\right], \mathbf{1}$, and $\left[\mathrm{PtCl}_{2}(\mathrm{tc})\right], \mathbf{2}$

\begin{tabular}{lccc}
\hline Compound & $\begin{array}{c}\mathrm{IC}_{50} \\
(\mu \mathrm{mol} \mathrm{L}\end{array} \pm$ s.d. $)$ & $\begin{array}{c}{\left[\mathrm{Pt}_{\mathrm{i}}\right] \times 10^{16}} \\
(\mathrm{~mol} / \mathrm{cell})\end{array}$ & $P$ \\
\hline dox & $17.70 \pm 0.9$ & - & $0.80^{\mathrm{a}}$ \\
tc & $52.37 \pm 3.1$ & - & $0.05^{\mathrm{a}}$ \\
$\mathbf{1}$ & $6.30 \pm 0.25$ & 5.6 & $1.76^{\mathrm{b}}$ \\
$\mathbf{2}$ & $9.39 \pm 0.20$ & 5.0 & $0.70^{\mathrm{b}}$ \\
\hline
\end{tabular}

$\mathrm{IC}_{50}$ is the concentration required to inhibit $50 \%$ of $\mathrm{K} 562$ cell growth. $\left[\mathrm{Pt}_{\mathrm{i}}\right]$ is the intracellular platinum concentration determined after incubating cells for 3 days with $\mathrm{IC}_{50}$ doses. $P$ is the total platinum in $n$-octanol divided by total platinum in the aqueous layer. a (from reference 47 ); ${ }^{\mathrm{b}}$ this work (the values are mean of triplicate determinations).

more potent than dox and complex 2, ca. 6 times more potent than tc. In addition, complex $\mathbf{1}$ is 1.5 times more active than complex 2 and 2.5 times more lipophilic. A correlation between lipophilicity and cytotoxic activity was also reported by Silva et al..$^{34}$ in a study of platinum(II) complexes with ligands derived from 1,3-propanediamine, whose difference lies in the carbon chain length.

\section{Drug accumulation after equitoxic exposure}

We have determined the intracellular concentration of the compounds after three days of incubation (Figure 2). The results obtained after incubation with equitoxic concentrations show that the same intracellular levels are necessary to attain a certain cytotoxic effect; for example, incubation with $\mathrm{IC}_{50}$ concentrations yields an intracellular platinum concentration of $5.2 \times 10^{-16} \mathrm{~mol} \mathrm{cell}^{-1}$ for both complexes.

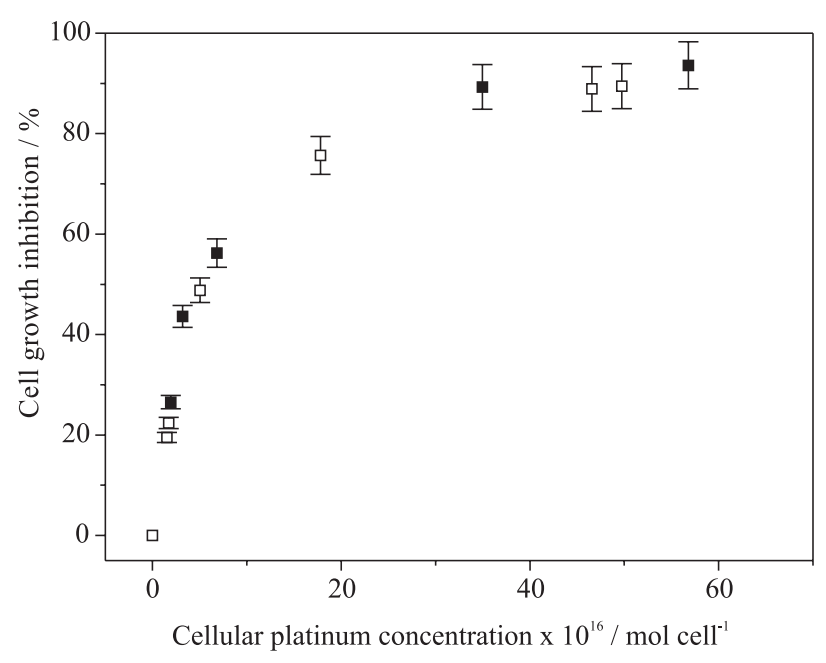

Figure 2. Correlation between cell growth inhibition and cellular platinum concentration after three-day incubation with equitoxic compound concentration. Symbols: compound $\mathbf{1}$ (open squares) and compound $\mathbf{2}$ (filled squares). Three independent experiments are represented. 


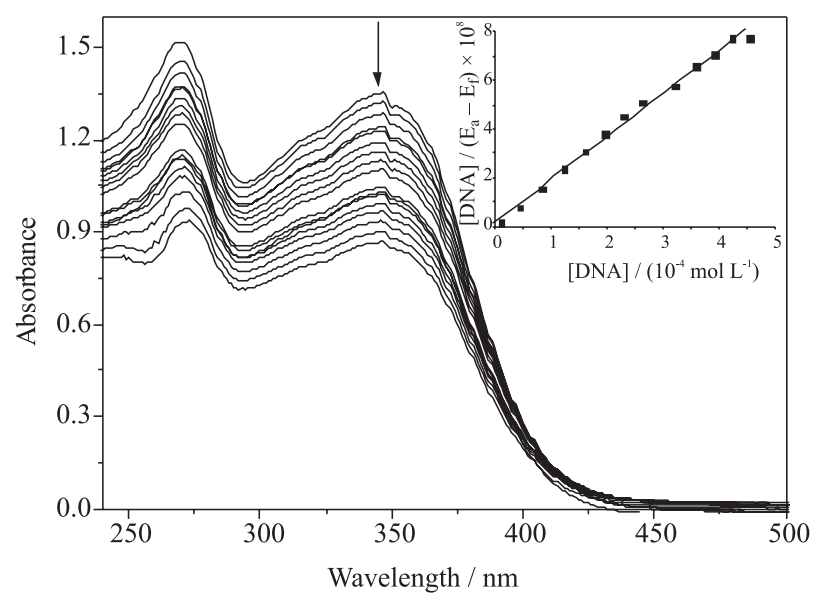

Figure 3. Spectra of solutions containing complex $1\left(1.0 \times 10^{-4} \mathrm{~mol} \mathrm{~L}^{-1}\right)$ and increasing concentrations of DNA in HEPES buffer $\mathrm{pH}$ 7.4. [DNA]: [complex 1] ranging from 0 to 4.5 . Inset: [DNA] $/\left(\varepsilon_{\mathrm{a}}-\varepsilon_{\mathrm{f}}\right)$ versus [DNA].

\section{Interactions with DNA}

As the mechanism of the antitumoral action of platinum compounds such as cisplatin involves binding to DNA, we have investigated the interactions of the compounds $\mathbf{1}$ and 2 with this intracellular target.

\section{Spectrophotometric studies}

We have registered the spectra of solutions of the complexes in the absence and presence of increasing concentrations of CT DNA. The addition of DNA induces a hypochromic effect, indicating that both $\mathrm{Pt}^{\mathrm{II}}$ complexes form a ternary complex with calf thymus DNA. A representative experiment obtained with complex 1 at $1 \times 10^{-4} \mathrm{~mol} \mathrm{~L}^{-1}$ and [DNA] / [1] varying from 0 to 4.5 is shown in Figure 3. In order to compare the binding strengths of the complexes, the binding constant, $\mathrm{K}$, was calculated according to the equation

$[\mathrm{DNA}] /\left(\varepsilon_{\mathrm{a}}-\varepsilon_{\mathrm{f}}\right)=[\mathrm{DNA}] /\left(\varepsilon_{0}-\varepsilon_{\mathrm{f}}\right)+1 / \mathrm{K}\left(\varepsilon_{0}-\varepsilon_{\mathrm{f}}\right)$,

where [DNA] is the concentration of DNA in base pairs, $\varepsilon_{\mathrm{a}}$ is the ratio of the absorbance / [Pt], $\varepsilon_{\mathrm{f}}$ is the extinction coefficient of the free $\mathrm{Pt}^{\mathrm{II}}$ complex and $\varepsilon_{0}$ is the extinction coefficient of the complex in the fully bound form. ${ }^{35}$ The ratio of slope to intercept in the plot of [DNA] $/\left(\varepsilon_{\mathrm{a}}-\varepsilon_{\mathrm{f}}\right)$ versus [DNA] gives the value of $\mathrm{K}$ (inset Figure 3). Complex $\mathbf{1}$ has a slightly lower affinity to DNA than complex $\mathbf{2}$, with $\mathrm{K}$ values of $3.85 \times 10^{4}$ and $5.43 \times 10^{4}$, respectively.

Circular dichroism (CD) spectroscopy is a useful technique for diagnosing changes in DNA morphology during drug-DNA interactions, as the CD signals are quite sensitive to the mode of DNA interactions with small molecules. ${ }^{36}$ The CD spectrum of the free DNA is composed of a positive band at $275 \mathrm{~nm}$, due to base stacking, and a negative one at $245 \mathrm{~nm}$, due to the right-handed helicity of B-DNA. ${ }^{37}$ Upon addition of $\mathbf{1}$ and $\mathbf{2}$, the CD spectrum of the resulting DNA undergoes an increase in both the positive and negative bands, as shown in Figure 4. This behavior indicates that the complexes probably intercalate into DNA, since it is generally accepted that the classical intercalation enhances the base stacking and stabilizes helicity, and thus increases intensities of the both bands, whereas simple groove binding and electrostatic interaction of small molecules show less or no perturbation on the base stacking and helicity bands. ${ }^{38,39}$ In addition, the changes induced by $\mathbf{2}$ are more significant than those by $\mathbf{1}$, in accordance to the affinity constants determined from UV-Vis data.

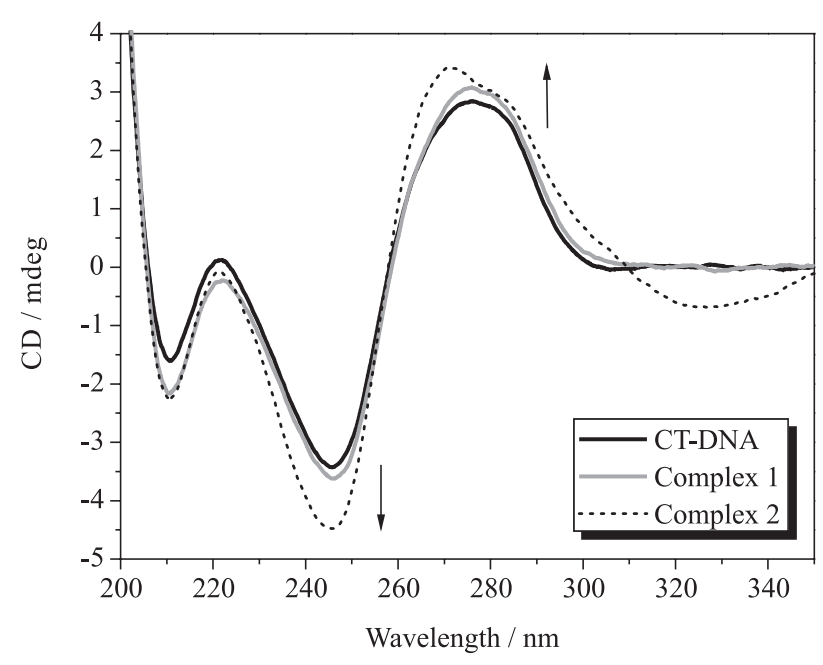

Figure 4. CD spectra of CT-DNA $\left(200 \mu \mathrm{mol} \mathrm{L}^{-1}\right)$ in $25 \times 10^{-3} \mathrm{~mol} \mathrm{~L}^{-1}$ PIPES buffer $\mathrm{pH} 7.0$ in the absence and the presence of $\mathbf{1}$ and $\mathbf{2}\left(100 \mu \mathrm{mol} \mathrm{L}^{-1}\right)$.

The interactions with DNA were also studied by fluorescence spectroscopy with the help of a fluorescent probe, the ethidium bromide. Eb is a well-known DNA intercalator, which is only poorly fluorescent but whose fluorescence enhances when intercalated between the base pairs. It can be used to evidence intercalating molecules because they can displace it from DNA sites leading to fluorescence quenching. We have firstly checked that $8 \mu \mathrm{mol} \mathrm{L}{ }^{-1}$ Eb saturate DNA sites in a $10 \mu \mathrm{mol} \mathrm{L}{ }^{-1}$ solution. The addition of the compounds $\mathbf{1}$ and $\mathbf{2}$ quenches the fluorescence emission with different affinities (Figure 5). The effects of free tc and dox are not very strong: to displace $50 \%$ of Eb from DNA sites it is necessary to add a molar ratio drug-to-Eb equal to 289 for dox and 106 for tc. Therefore, to attain the same quenching it is necessary to add approximately 2.7 times more doxycycline than tetracycline to the solution. By comparing the results obtained with the proligands to those with their respective $\mathrm{Pt}^{\mathrm{II}}$ complexes, one 

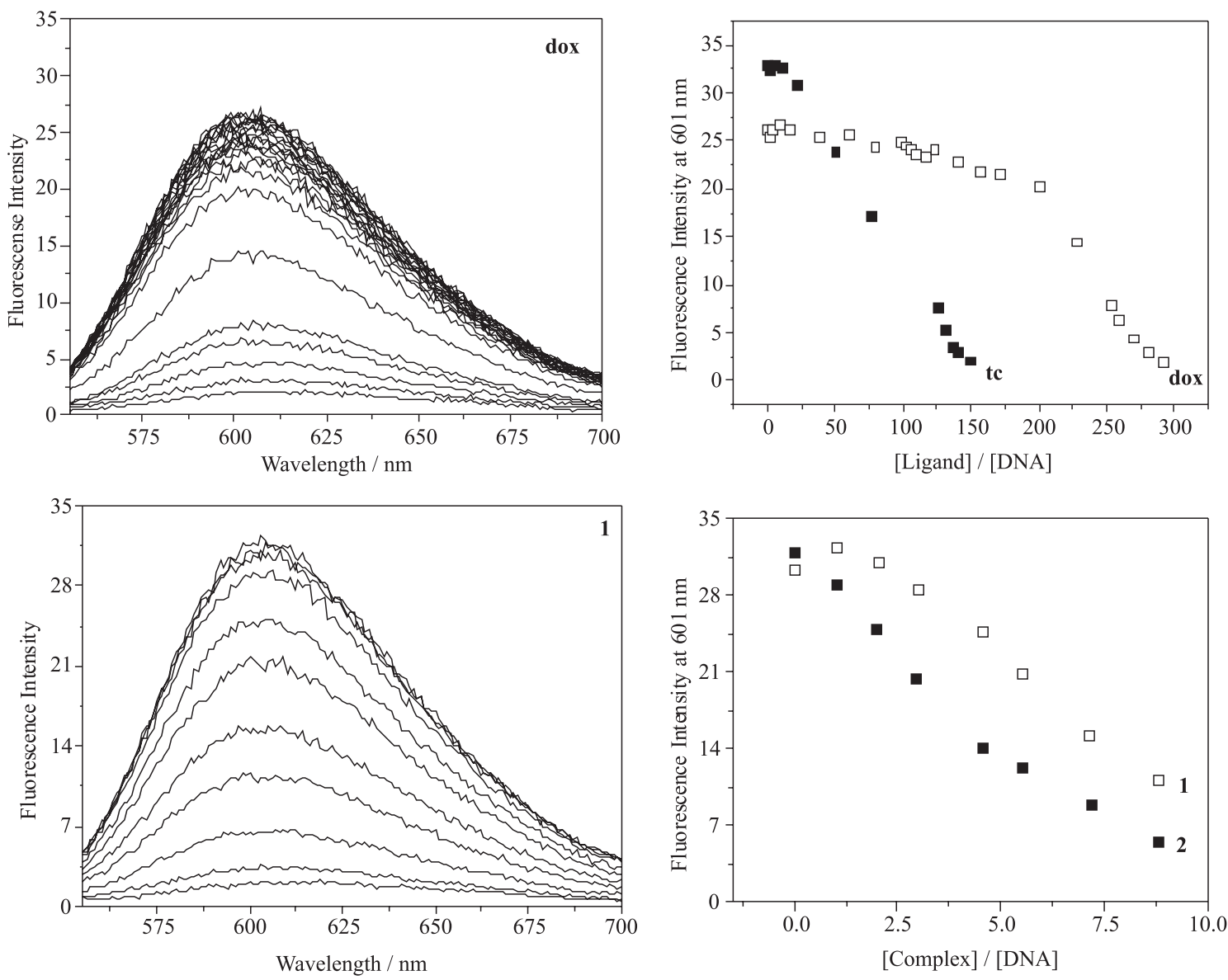

Figure 5. Effect of doxycycline (dox), tetracycline (tc) and their $\mathrm{Pt}^{\mathrm{tI}}$ compounds, 1 and 2, respectively, on the binding of Eb to calf-thymus DNA. The DNA concentration was $10 \mu \mathrm{mol} \mathrm{L}^{-1}$ and that of $\mathrm{Eb} 8 \mu \mathrm{mol} \mathrm{L}^{-1}$, in TRIS-HCl buffer at $\mathrm{pH} 7.3$. The wavelength of excitation was $546 \mathrm{~nm}$. Top: left - Fluorescence emission spectra in the presence of dox concentrations ranging from 0 to $2.91 \times 10^{-3} \mathrm{~mol} \mathrm{~L}^{-1}$. Right: Fluorescence intensity at $601 \mathrm{~nm}$ as a function of ligand-to-DNA molar ratio. Bottom: Left - Fluorescence emission spectra in the presence of compound 1 concentrations ranging from 0 to $87.75 \mu$ mol $\mathrm{L}^{-1}$. Right - Fluorescence intensity at $601 \mathrm{~nm}$ as a function of complex-to-DNA molar ratio.

observes a significant increase in the affinity for DNA. The $\mathrm{Pt}^{\mathrm{HI}}$ complex of tc is approximately 20 times as potent as tc in displacing Eb from DNA, and the $\mathrm{Pt}^{\mathrm{II}}$ complex of dox is approximately 33 times as potent as dox. From a plot of the fluorescence signal at $601 \mathrm{~nm}$ as a function of the molar ratio complex-to-DNA one can estimate the molar ratio needed to displace $50 \%$ of the added Eb from DNA sites: 231 for free dox, 85 for free tc, 4 for $\left[\mathrm{PtCl}_{2}(\mathrm{tc})\right]$ and 7 for $\left[\mathrm{PtCl}_{2}(\mathrm{dox})\right]$. These results indicate that the agents competitively displace Eb from the DNA molecule. Khan et al..$^{30}$ performed a study of the interactions of tc and DNA in the absence and presence of copper(II) ions and observed a 2.6-fold increase in the affinity to DNA. In our study, $\mathrm{Pt}^{\mathrm{II}}$ coordination increases dox affinity to DNA by a factor of 33 and tc affinity by a factor of 21 .

\section{DNA thermal denaturation}

The melting curves of CT-DNA in the absence and presence of $\mathbf{1}$ and $\mathbf{2}$ are presented in Figure 6. The melting

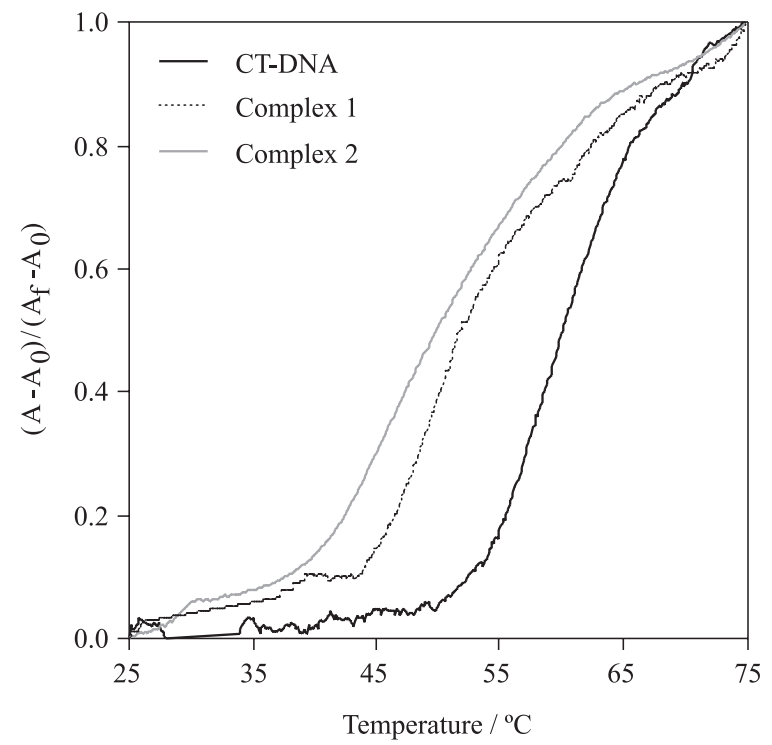

Figure 6. Melting curves of CT-DNA $\left(100 \mu \mathrm{mol} \mathrm{L}^{-1}\right)$ at $260 \mathrm{~nm}$ in the absence and the presence of $\mathbf{1}$ or $\mathbf{2}$ at $\mathrm{r}=0.25 . \mathrm{A}_{0}, \mathrm{~A}_{\mathrm{f}}$ and $\mathrm{A}$ are the absorption intensities at $25,75^{\circ} \mathrm{C}$ and at a given temperature between 25 and $75^{\circ} \mathrm{C}$, respectively. 
temperature $\left(\mathrm{T}_{\mathrm{m}}\right)$ determined for CT-DNA was $60.3{ }^{\circ} \mathrm{C}$. In the presence of $\mathbf{1}$ and $\mathbf{2}$, the $\mathrm{T}_{\mathrm{m}}$ decreased to 52.4 and $50.0{ }^{\circ} \mathrm{C}$, representing a $\Delta \mathrm{T}_{\mathrm{m}}$ of -7.9 and $-10.3^{\circ} \mathrm{C}$, respectively. The decrease in $\mathrm{T}_{\mathrm{m}}$ can be attributed to the formation of cross-links between the complexes and DNA, reducing the double-helical stability. This has been demonstrated earlier for several platinum complexes with similar results. ${ }^{40,41}$

\section{Plasmid DNA cleavage}

No plasmid DNA cleavage was observed for $\mathbf{1}$ and $\mathbf{2}$, as evidenced by the constant amount of supercoiled DNA (F I) and open circular DNA (F II) after the treatment with the complexes, even after long incubation times of $20 \mathrm{~h}$ at $50^{\circ} \mathrm{C}$ and concentrations up to $500 \mu \mathrm{mol} \mathrm{L}{ }^{-1}$ (Figure 7). Many platinum complexes, such as cisplatin, interact with DNA by a binding mode that does not promote DNA cleavage. ${ }^{42}$

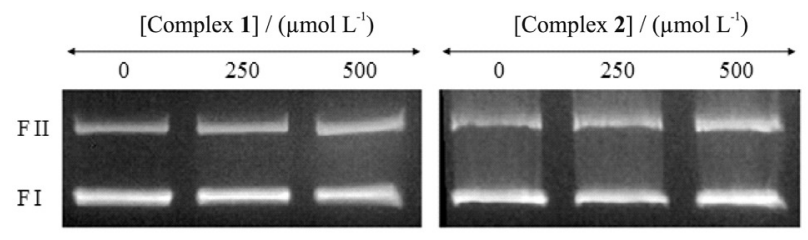

Figure 7. Agarose gel eletrophoresis of pBSK-II plasmid DNA (330 ng, $25 \mu \mathrm{mol} \mathrm{\textrm {L } ^ { - 1 }}$ in bp) treated with $\mathbf{1}$ and $\mathbf{2}$ at the indicated concentrations for $20 \mathrm{~h}$ at $50{ }^{\circ} \mathrm{C}$ in PIPES buffer $\left(25 \times 10^{-3} \mathrm{~mol} \mathrm{~L}^{-1}, \mathrm{pH} 7.0\right)$.

Plasmid DNA interaction by agarose gel mobility shift assay

Since no evidence of plasmid DNA cleavage was found by treatment with $\mathbf{1}$ and $\mathbf{2}$, their ability to bind and consequently change the eletrophoretic mobility of supercoiled DNA was assayed. Both complexes are able to decrease the mobility of supercoiled DNA in a concentration-dependent manner from 250 to $1000 \mu \mathrm{mol} \mathrm{L} \mathrm{L}^{-1}$ (Figure 8). Futhermore, 2 seems able to effect stronger binding with plasmid DNA compared to $\mathbf{1}$ at the same conditions, since the alteration of migration of FI is clearly seen at $100 \mu \mathrm{mol} \mathrm{L} \mathrm{L}^{-1}$ for complex 2 in contrast to $250 \mu \mathrm{mol} \mathrm{L} \mathrm{L}^{-1}$ for complex $\mathbf{1}$. The alteration of supercoiled plasmid DNA migration is typically caused by compounds that alter DNA topology such as intercalators. It has also been reported that non-intercalators such as minor groove binders could have a similar performance. ${ }^{43}$ Some platinum complexes present this type of binding, which is in good agreement with citotoxicity and anticancer properties. ${ }^{44-46}$

\section{Cellular uptake of platinum(II) compounds}

Our results have shown that complex $\mathbf{1}$ has a slightly lower affinity for DNA than complex 2 despite the fact
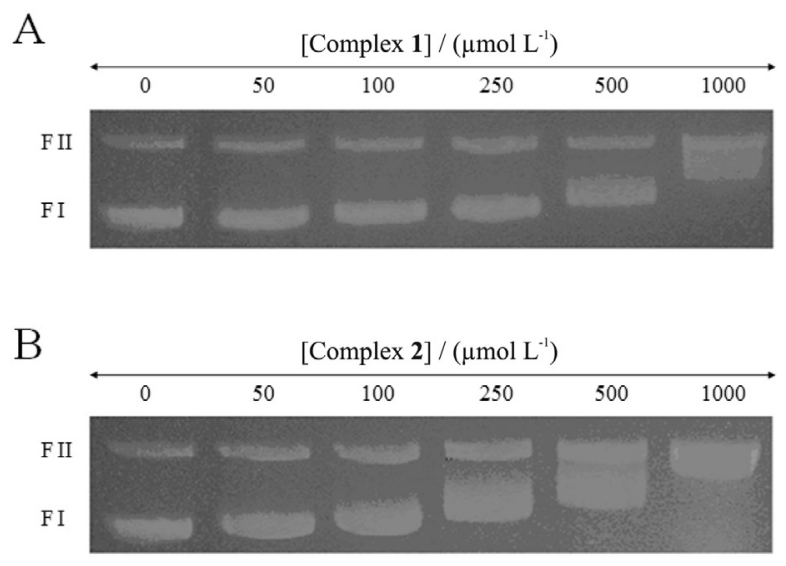

Figure 8. Agarose gel eletrophoresis of pBSK-II plasmid DNA (330 ng, 25 $\mu \mathrm{mol} \mathrm{L} \mathrm{L}^{-1}$ in bp) treated with $\mathbf{1}(\mathrm{A})$ and $\mathbf{2}(\mathrm{B})$ at the indicated concentrations for $16 \mathrm{~h}$ at $50^{\circ} \mathrm{C}$ in PIPES buffer $\left(25 \times 10^{-3} \mathrm{~mol} \mathrm{~L}^{-1}, \mathrm{pH} 7.0\right)$.

that it is more cytotoxic. Complex $\mathbf{1}$ is also more lipophilic and this can modulate its uptake in cells. In order to investigate if the cytotoxic activity was related to the uptake rate we have followed the variation of the intracellular concentration of platinum, $[\mathrm{Pt}]_{\mathrm{i}}$, as a function of the incubation time (Figure 9). The intracellular concentration increases linearly with time up to $10 \mathrm{~min}$ and the curve approaches saturation after $25 \mathrm{~min}$ for compound $\mathbf{1}$ and $50 \mathrm{~min}$ for compound 2 . The initial rate of uptake can be calculated by the slope of the tangent to the curve $[\mathrm{Pt}]_{\mathrm{i}}=\mathrm{f}(\mathrm{t})$. The uptake of compound $\mathbf{1}$ is faster than that of compound 2: we obtain a rate of $2.7 \times 10^{-18} \mathrm{~mol} \mathrm{cell}^{-1} \mathrm{~s}^{-1}$ $\left(\right.$ kin $=2.6 \times 10^{-13} \mathrm{~L}$ cell-1 $\left.\mathrm{s}^{-1}\right)$ for compound $\mathbf{1}$ and $8.3 \times 10^{-19} \mathrm{~mol} \mathrm{cell}^{-1} \mathrm{~s}^{-1}\left(\right.$ kin $=8.3 \times 10^{-14} \mathrm{~L}$ cell $\left.^{-1} \mathrm{~s}^{-1}\right)$ for compound 2 . The ratio of the uptake rate of the doxycycline complex divided by that of the tetracycline compound is $c a$. 3. This can be correlated to the difference in the dose-

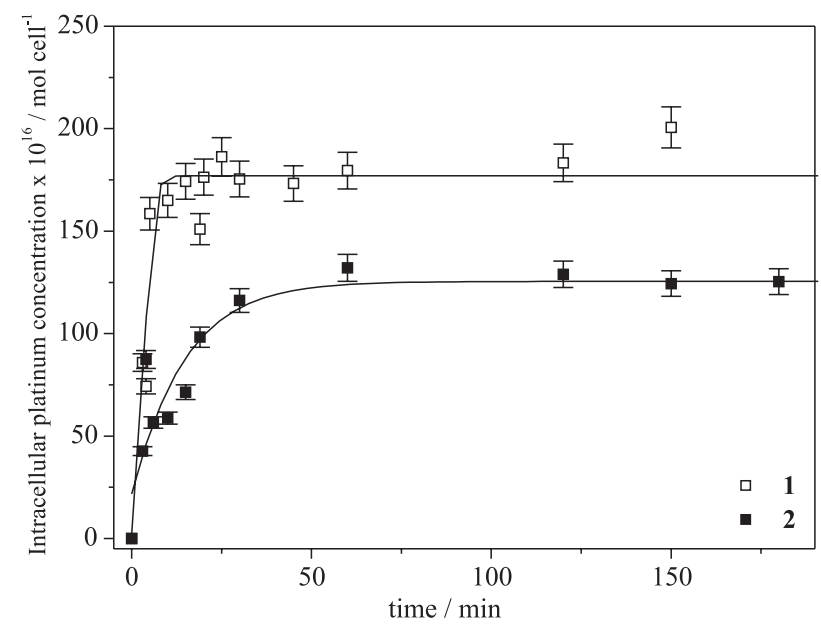

Figure 9. Uptake of platinum(II) compounds of tetracycline (filled squares) and of doxycycline (open squares) by K562 cells. $1 \times 10^{6}$ cells were incubated with $1 \times 10^{-5} \mathrm{~mol} \mathrm{~L}^{-1}$ of each compound. Three independent experiments are represented. 
response curves of the complexes, strongly suggesting that more tetracycline complex is needed to attain a given cytotoxic effect because it enters cells more slowly.

\section{Intracellular DNA binding}

We have shown that complexes $\mathbf{1}$ and $\mathbf{2}$ enter and are accumulated in cells and that they interact with DNA in vitro. Furthermore, we have extracted DNA from cells after incubating with $\mathbf{1}$ and $\mathbf{2}$ and quantified the adducts formed.

Cells were incubated with increasing concentrations of both complexes for $2 \mathrm{~h}$ prior to DNA extraction and platinum content determination. In Figure 10, the amount of platinum bound to DNA is plotted as a function of the concentration of $\mathbf{1}$ and $\mathbf{2}$ in the incubation medium. The number of Pt-DNA adducts increases with the concentration of the complex. Therefore, platinum-DNA adducts are formed inside cells when they are exposed to $\mathbf{1}$ and $\mathbf{2}$.

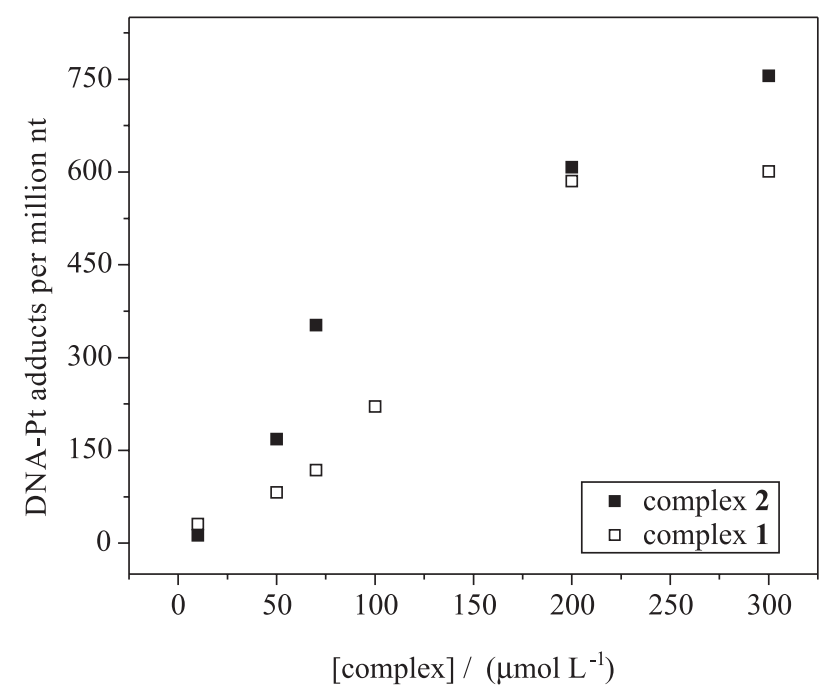

Figure 10. Amount of platinum bound to DNA as a function of the concentration of complex $\mathbf{1}$ (open squares) or complex $\mathbf{2}$ (filled squares) added to the incubation medium. $1 \times 10^{6} \mathrm{~K} 562$ cells were incubated with different concentrations of complexes ranging from 0 to $300 \mu \mathrm{mol} \mathrm{L}^{-1}$ for $2 \mathrm{~h}$. The values are averages of three separate measurements.

\section{Macrophages viability}

As macrophages play an important role in antitumor immunity, producing important antitumor molecules such as TNF- $\alpha$ and nitric oxide, we investigated the effect of our compounds on mouse peritoneal macrophage viability. Both compounds do not affect the viability of mouse peritoneal macrophages up to $16 \mu \mathrm{mol} \mathrm{L} \mathrm{L}^{-1}$ after a 24 or $48 \mathrm{~h}$-incubation (data not shown). After $72 \mathrm{~h}$ of incubation, the $\mathrm{IC}_{50}$ values were $18 \mu \mathrm{mol} \mathrm{L}-1$ for compound $\mathbf{1}$ and $34 \mu \mathrm{mol} \mathrm{L}^{-1}$ for compound 2 (Figure 11). Therefore, the

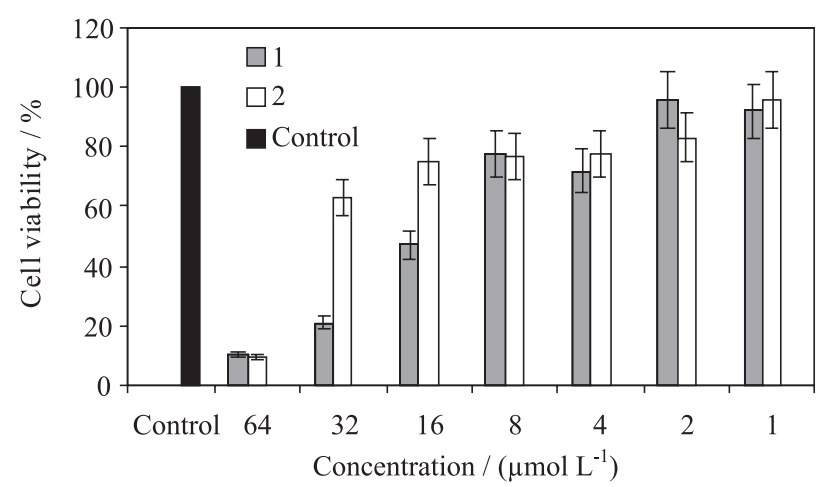

Figure 11. Effect of compounds 1 and 2 on macrophage viability, after $72 \mathrm{~h}$ of incubation. Values are representative of two independent experiments.

doxycycline complex is more toxic to macrophages than the tetracycline counterpart.

\section{Conclusions}

We have shown that the interactions of tetracycline and doxycycline with DNA are not very strong, but for their $\mathrm{Pt}^{\mathrm{II}}$ compounds these interactions are significant. This enhancement in the affinity of the antibiotics for DNA is worth to note and suggests that interaction with DNA can be crucial for the cytotoxic effect of the compounds. The fact that the complexes displace Eb from DNA sites, enhance base stacking and stabilize helicity points to an intercalative mechanism. Both complexes are able to decrease the eletrophoretic mobility and the melting temperature of DNA in a concentration-dependent manner.

Our results demonstrated that platinum(II) complexes of tetracycline and doxycycline enter cells, bind to DNA and inhibit tumoral cell growth at a concentration in which they do not affect macrophage viability. The platinum(II) complex of doxycycline is more lipophilic and enters cells at a higher rate than its tetracycline counterpart and this seems to be the reason for its higher cytotoxic activity.

\section{Supplementary Information}

Supplementary Information is available free of charge at http://jbcs.org.br, as PDF file.

\section{Acknowledgments}

This work was supported by grants from CNPq (Conselho Nacional de Desenvolvimento Científico e Tecnológico, Brazil), Instituto Nacional de Ciência e Tecnologia de Catálise em Sistemas Moleculares e Nanoestruturados (INCT-Catálise), Instituto Nacional de Ciência e Tecnologia de Biologia Estrutural e Bioimagem (INBEB) and FAPEMIG (Fundação de Amparo à Pesquisa de Minas Gerais, Brazil). 


\section{References}

1. Rosenberg, B. L.; Camp, V.; Cancer Res. 1970, 30, 1799.

2. Lippert, B.; Cisplatin: Chemistry and Biochemistry of a Leading Anticancer Drug, VHCA and Wiley-VCH: Weinheim, 1999.

3. Rosenberg, J. E.; Carrol, P. R.; Small, E. J.; J. Urol. 2005, 174,14 .

4. Pisters, K. M.; Le Chevalier, T.; J. Clin. Oncol. 2005, 23, 3270.

5. Jamieson, E. R.; Lippard, S. J.; Chem. Rev. 1999, 99, 2467.

6. Fichtinger-Schepman, A. M. J.; Van der Veer, J. L.; Den Hartog, J.H.J.; Lohman, P. H. M.; Reedijk. J.; Biochemistry, 1985, 24, 707.

7. Dzamitika, S.; Salerno, M.; Pereira-Maia, E.; Le Moyec, L.; Garnier-Suillerot, A.; J. Bioenerg. Biomembr. 2006, 38, 11.

8. Gately, D. P.; Howell, S. B.; Br. J. Cancer. 1993, 67, 1171.

9. Pereira-Maia, E.; Garnier-Suillerot, A.; J. Biol. Inorg. Chem. 2003, 8, 626 .

10. Ishida, S.; Lee, J.; Thiele, D. J.; Herskowitz, I.; Proc. Natl. Acad. Sci. USA 2002, 99, 14298.

11. Katano, K.; Kondo, A.; Safaei, R.; Holzer, A.; Samimi, G.; Mishima, M.; Kuo, Y; Rochdi, M.; Howell, S. B.; Cancer Res. 2002, 62, 6559 .

12. César, E.; Almeida, M.; Fontes, A. P.; Pereira-Maia, E.; GarnierSuillerot, A.; Couri, M.; Felício, E.; J. Inorg. Biochem. 2003, 95, 297.

13. Couria, M. R. C.; Almeida, M.; Fontes, A. P.; Chaves, J. A. S.; César, E. T.; Alves, R. J.; Pereira-Maia, E. C.; Garnier-Suillerot, A.; Eur. J. Inorg. Chem. 2006, 1868.

14. dePaula,F.C.S.; Carvalho, S.;Duarte,H.A.;Paniago,E.; Mangrich, A. S.; Pereira-Maia, E. C.; J. Inorg. Biochem. 1999, 76, 221.

15. Brion, M.; Berthon, G.; Fourtillan, J. B.; Inorg. Chim. Acta 1981, 55, 47.

16. Lambs, L.; Venturini, M.; Decock-Le Révérend, B.; Kozlowski, H.; Berthon, G.; J. Inorg. Biochem. 1988, 33, 193.

17. Chopra, I.; Drug Resist. Updat. 2002, 5, 119.

18. Salyers, A. A.; Speer, B. S.; Shoemaker, N. B.; Mol. Microbiol. 1990, 4, 151.

19. Davies, J.; Science 1994, 264, 375.

20. Nikaido, H.; Science 1994, 264, 382.

21. Saenger, W.; Orth, P.; Kisker, C.; Hillen, W.; Hinrichs, W.; Angew. Chem. Int. Ed. 2000, 39, 2042.

22. Chartone-Souza, E.; Loyola, T. L.; Bucciarelli-Rodriguez, M.; Menezes, M. A.; Rey, N.A.; Pereira-Maia, E. C.; J. Inorg. Biochem. 2005, 99, 1001.

23. Guerra, W.; Azevedo, E. A.; Monteiro, A. R. S.; Chartone-Souza, E.; Nascimento, A. M. A.; Bucciarelli-Rodriguez, M.; Fontes, A. P. S.; Le Moyec, L.; Pereira-Maia, E. C.; J. Inorg. Biochem. 2005, 99, 2348.

24. Guerra, W.; Silva, I. R.; Azevedo, E. A.; Monteiro, A. R. S.; Bucciarelli-Rodriguez, M.; Chartone-Souza, E.; Silveira, J. N.; Fontes, A. P. S.; Pereira-Maia, E. C.; J. Braz. Chem. Soc. 2006, 17, 1627.
25. Santos, H. F.; Marcial, B. L.; Miranda, C. F.; Costa, L. A. S.; Almeida, W. B.; J. Inorg. Biochem. 2006, 100, 1594.

26. Marcial, B. L.; Costa, L. A. S.; De Almeida, W. B.; Dos Santos, H. F.; J. Braz. Chem. Soc. 2008, 19, 1437.

27. Egeblad, M.; Werb, Z.; Nat. Rev. Cancer 2002, 2, 161.

28. Overall, C.M.; Lopez-Otin, C.; Nat. Rev. Cancer 2002, $2,657$.

29. Garcia, R. A.; Pantazatos, D. P.; Gessner, C. R.; Go, K. V.; Woods Jr., V. L.; Villarreal, F. J.; Mol. Pharmacol. 2005, 67, 1128.

30. Khan, A. M.; Musarrat, J.; Int. J. Biol. Macromol. 2003, 33, 49.

31. Khan, A. M.; Mustafa, J.; Musarrat, J.; Mut. Res. 2003, 525, 109.

32. Tan, M. W.; Rahme, L. G.; Sternberg, J. A.; Tompkins, R. G.; Ausubel, F. M.; Proc. Natl. Acad. Sci. USA 1999, 96, 2408.

33. Rey, N. A.; Neves, A.; Silva, P. P.; Paula, F. C. S.; Silveira, J. N.; Botelho, F. V.; Vieira, L. Q.; Pich, C. T.; Terenzi, H.; PereiraMaia, E. C.; J. Inorg. Biochem. 2009, 103, 1323.

34. Silva, H.; Barra, C. V.; Costa, C. F.; Almeida, M.; César, E. T.; Silveira, J. N.; Garnier-Suillerot, A.; Paula, F. C. S.; PereiraMaia, E. C.; Fontes, A. P.; J. Inorg. Biochem. 2008, 102, 767.

35. Kumar, R. S.; Arunachalam, S.; Periasamy, V. S.; Preethy, C. P.; Riyasdeen, A.; Akbarsha, M. A.; J. Inorg. Biochem. 2009, 103, 117.

36. Garbett, N. C.; Ragazzon, P. A; Chaires, J. B.; Nature Protocols 2007, 2, 3166.

37. Chen, Z.; Wang, X.; Li, Y.; Guo, Z.; Inorg. Chem. Comm. 2008, 11,1392 .

38. Chen, L. M.; Liu, J.; Chen, J. C.; Shi, S.; Tan, C. P.; Zheng, K. C.; Ji, L. N.; J. Mol. Struct. 2008, 881, 156.

39. Keck, M. V.; Lippard, S. J.; J. Am. Chem. Soc. 1992, 114, 3386.

40. Mitsopoulou, C. A.; Dagas, C. E.; Makedonas, C.; J. Inorg. Biochem. 2008, 102, 77.

41. Tian, T.; Mutikainen, I.; Gilles, P. van W.; Aliaga-Alcalde, N.; Reedijk, J.; J. Inorg. Biochem. 2009, 103, 1221.

42. Keene, F. R.; Smith, J. A.; Collins, J. G.; Coord. Chem. Rev. 2009, 253, 2021.

43. Otero, L.; Smircich, P.; Vieites, M.; Ciganda, M.; Cardoso, S. P.; Terenzi, H.; Cerecetto, H.; Gambino, D.; Garat, B.; J. Inorg. Biochem. 2007, 101, 74.

44. Xu, Z.; Zhang, Y.; Xue, Z.; Yang, X.; Wu, Z.; Guo, Z.; Inorg. Chim. Acta 2009, 362, 2347.

45. Halámiková, A.; Heringová, P.; Kašpárková, J.; Intini, F. P.; Natile, G.; Nemirovskic, A.; Gibsonc, D.; Brabec, V.; J. Inorg. Biochem. 2008, 102, 1077.

46. Brabec, V.; Christofis, P.; Slámová, M.; Kostrhunová, H.; Nováková, O.; Najajreh, Y.; Gibson, D.; Kašpárková, J.; Biochem. Pharmacol. 2007, 73, 1887.

47. Liu, Y.; Ramamurthy, N. S.; Marecek, J.; Lee, H. M.; Chen, J. L.; Ryan, M. E.; Rifkin, B. R.; Golub, L. M.; Curr. Med. Chem. 2001, 8, 243.

Received: September 14, 2009 Web Release Date: April 12, 2010 


\section{Platinum(II) Compounds of Tetracyclines as Potential Anticancer Agents: Cytotoxicity, Uptake and Interactions with DNA}

\section{Priscila P. Silva, ${ }^{a}$ Flávia C. S. de Paula, ${ }^{a}$ Wendell Guerra, ${ }^{a, \#}$ Josianne N. Silveira, ${ }^{b}$} Françoise V. Botelho, ${ }^{c}$ Leda Q. Vieira, ${ }^{c}$ Tiago Bortolotto, ${ }^{d}$ Franciele L. Fischer, ${ }^{d}$

Giselle Bussi, ${ }^{d}$ Hernán Terenzid ${ }^{d}$ and Elene C. Pereira-Maia $* a$

${ }^{a}$ Departamento de Química, ${ }^{b}$ Departamento de Análises Clínicas e Toxicológicas, ${ }^{c}$ Departamento de Bioquímica e Imunologia, Universidade Federal de Minas Gerais, Av. Antônio Carlos, 6627 - Pampulha, 31270-901 Belo Horizonte - MG, Brazil

${ }^{d}$ Centro de Biologia Molecular Estrutural, Departamento de Bioquímica, Universidade Federal de Santa Catarina, Campus Reitor João David Ferreira Lima, Bairro Trindade, 88040-970 Florianópolis - SC, Brazil

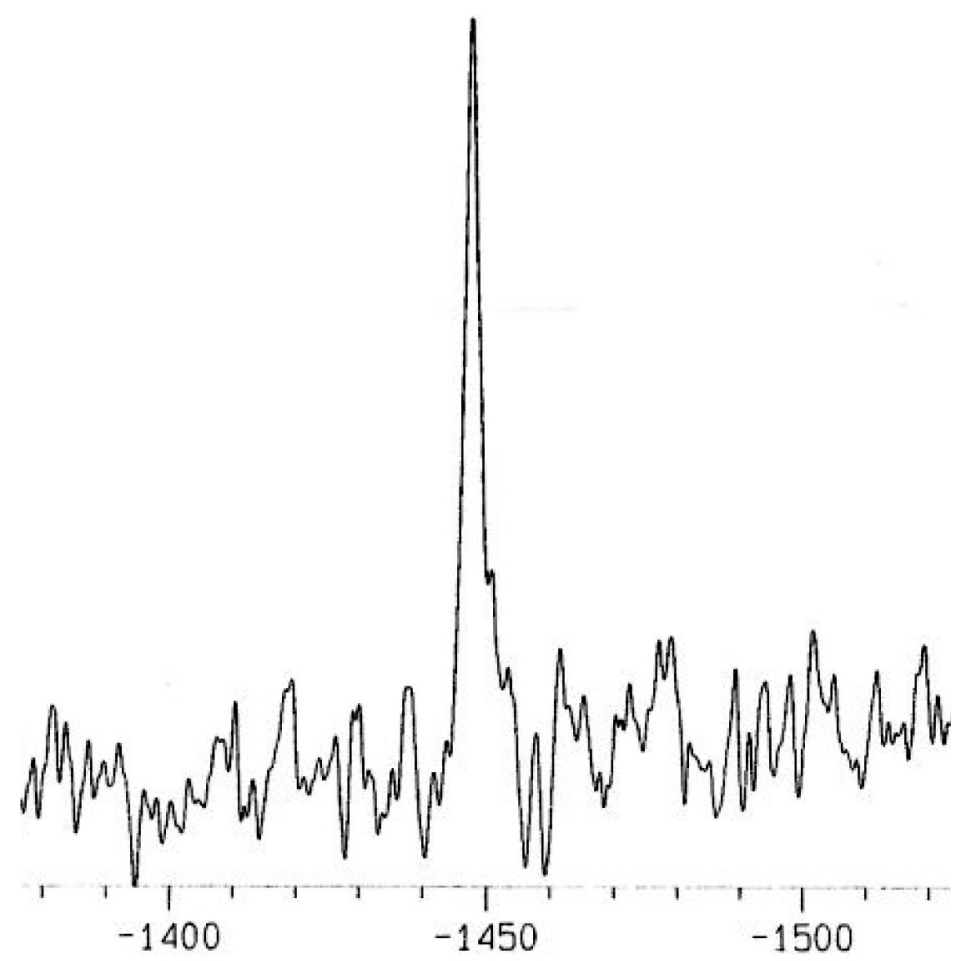

Figure S1. ${ }^{195} \mathrm{Pt}$ NMR spectrum of complex 2 in $\mathrm{dmf}-d_{7}$.

*e-mail: elene@qui.ufmg.br

" Present Address: Instituto de Química, Universidade Federal de Uberlândia, Brazil 


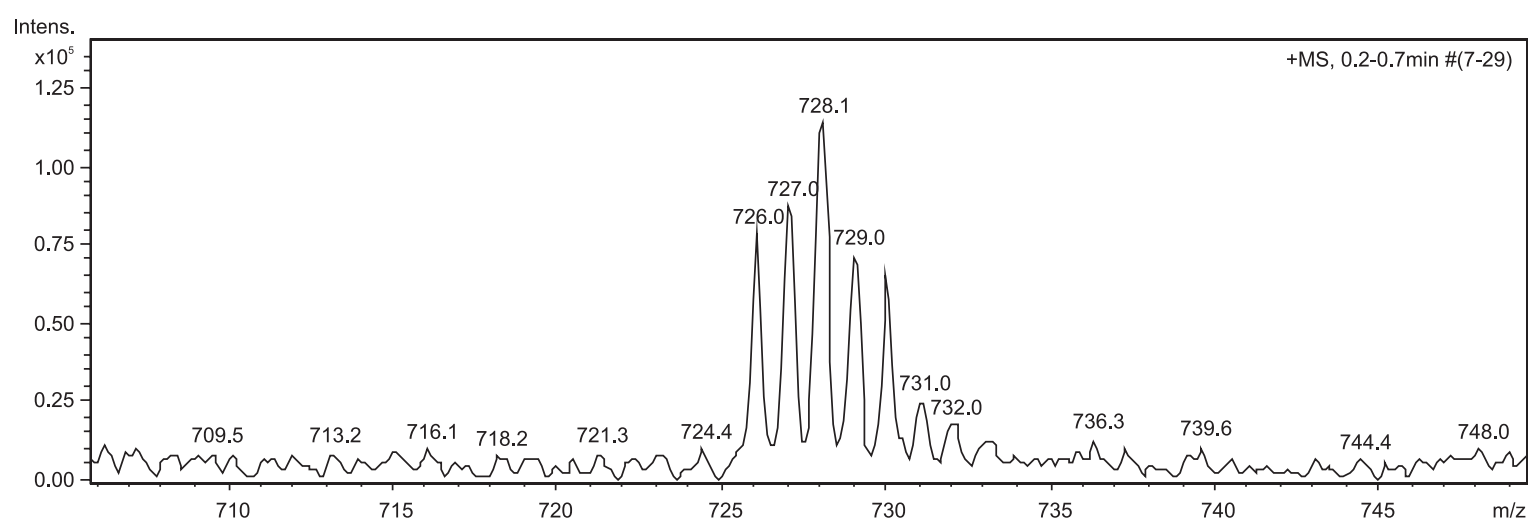

Figure S2. ESI-MS spectrum of complex 1 in positive mode.

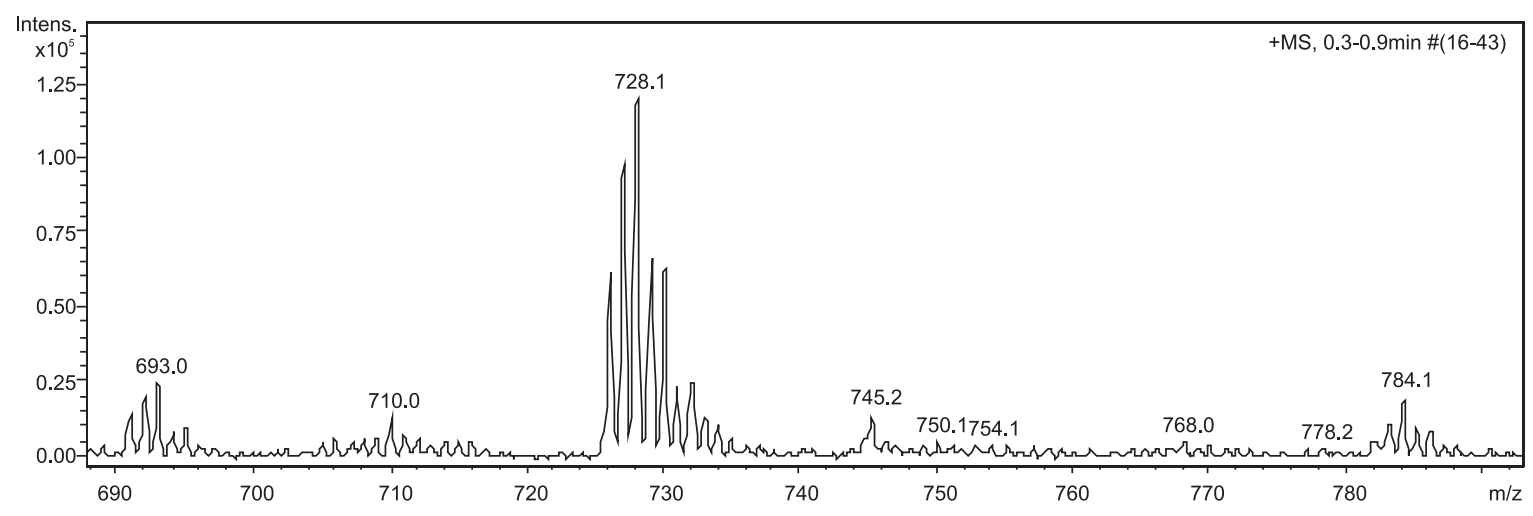

Figure S3. ESI-MS spectrum of complex 2 in positive mode. 